\title{
GREAT ART SHOULD SLOW US DOWN: "PARTICIPATIVE THINKING" IN THE WORLD AND AS THE WORLD OF CARYL EMERSON
}

\section{David Bethea}

“The words won't go away." Would it were that simple. Perhaps they don't just go away, in the sense that they are still being written and that they are out there, somewhere, circulating. But do they stick any longer? That is the question. Is the circulating a fruitless spinning, the rainbow top we get on our macs when something is hung up and the electronic gears can't seem to mesh with the other side? Or is it a way, as we go about our lives and search for meaning, to send a message in a bottle to the future - one that we hope will be read? It is of course both, hence the double-voicedness in the title. It is not only that other art forms, more performance-based and typically visually arresting, are crowding out the verbal in dialogues about aesthetics: the taut yet graceful balletic body that coils and extends through musical prompt; the cutting and juxtaposing of moving images that creates story in film; the all-the-world's-a-stage of the theater, where the footlights seem magically to propel the talking and gesturing and orchestrated activity on one side of the invisible divide through to the other side; and the song, now slimming down to chatter-like recitative or fattening out to full-blown aria, that is acted out of the opera. How can words on a page compete any longer with the synaesthetic sensory bombardment of these and other like modes? How can they be read and absorbed against the counterveiling pressures of ever greater speed and the glibness of the sound-bite?

Well, they can't, except in one essential way, which is also why they won't go away. They are the carriers of ideas. Not ideas as Wikipedia entries, chunks of freely edited semantic material, but ideas as intellectual duets, or better, elaborate dance routines where different bodies and spirits touch in unanticipated places and learn about each other, trying to keep the movement going in an innerly synchronized direction, a direction that takes in enough of the past and present to anticipate the future. Ideas that impart not only 
new information, which in and of itself can be sterile, but information plus energy, which in this new and enhanced configuration has been deeply and irresistibly eroticized. And by eroticized I do not mean determined by sexual motifs and traces. Rather I mean suffused with a kind of mental life force that is necessary for our species' survival. It is this version of ideas for which Caryl Emerson was born. They are her trademark, her special brand.

In the remarks to follow I do my best not to write hagiography, which on the one hand is bound to make the subject uncomfortable, and on the other does not do justice to the intellectual substance of her many achievements. What I attempt to do instead is make some generalizations about how CE's approach to ideas works and then apply those overarching comments to her more specific areas of interest and expertise: 1) Bakhtinian thought as internalized worldview and as something more than postmodern situational ethics and aesthetics; 2) the way the classics of Russia's literary Golden Age (Pushkin, Dostoevsky, Tolstoy, Chekhov) still speak to us today, but very much from within their specific "voice zones"; and 3) the issues raised by artistic "transposition" (a specific term CE uses to describe rendering the product of one art form/mode, say Pushkin's Shakespearean historical tragedy Boris Godunov, into another, say Musorgsky's opera of the same name), especially with regard to how a verbal artifact undergoes change as it enters musically or theatrically aestheticized space.

I begin with an example from Vladimir Solov'ev, a thinker (moral philosopher) congenial both to Bakhtin and to CE. Just as CE claims that her subject "lived by ideas," ${ }^{1}$ so too, I hope to show, does CE. In his remarkable article on Darwin entitled "Beauty in Nature" [Krasota v prirode, 1889], Solov'ev discusses different examples of beauty and ugliness in the natural world against the background of On the Origin of Species (1859). A diamond is beautiful in his reading because it brings two elements together and transforms, or transfigures [preobrazhaet], them into a third:

The beauty of a diamond, which is in no way inherent in its material substance (as that matter is precisely the same thing as we would find in an ugly piece of coal), depends, apparently, on the play of light rays on its facets... This means that the beauty, which belongs neither to the material body of the diamond, nor to the light ray refracted in it, is the product of

1 When citing from Caryl Emerson's essays in the present volume I will give the title of the chapter and the page number: "The Early Philosophical Essays," 52. 
both of them in their interaction [v ikh vzaimodeistvii]. The play of light, retained and transformed by that body, covers over completely the latter's crudely material appearance, and while the dark matter of the carbon is present here, as it is in the coal, it is so only in the form of a bearer of another, luminescent origin, which reveals in this play of colors its proper content.... In this unmerged and undivided [Solov'ev's signature nesliiannyi inerazdel'nyi-DMB] union of matter and light both preserve their natures, neither one nor the other is visible alone, but rather there is visible a single light-bearing matter and a single incarnated light — enlightened coal and a stone rainbow. ${ }^{2}$

Note that for Solov'ev it is not the rock per se or the light per se, but what grows out of the one being suffused by the other into a third, that catches his attention. The matter and the light "mutually penetrate each other [vzaimno pronikaiut drug druga] in a kind of ideal balance." ${ }^{3}$ This ideal-balance aspect, neither static nor outside time/history, is the essential ingredient in Solov'ev's three-part thinking; it serves the "Sophianic" role of revealing how the separate parts, through their emergent form and function, elide to produce, as it were, "enlightened matter." In the realm of ethics Solov'ev calls this love; in the realm of aesthetics, beauty; in the realm of ideas, truth. In another example that fully acknowledges Darwin's magnificent achievement but departs from the naturalist on aesthetic grounds (Darwin was also enraptured by the beauty in nature, but over the years came to believe that beauty had no connection to a higher intelligence), Solov'ev argues that the nightingale's song ${ }^{4}$ cannot be explained exclusively from origins: yes, there is a utilitarian impulse (mating) that coexists in the material result, but there is also the recognition that the biological need is transformed along the way into something of genuine aesthetic value, and that thing of beauty can and should be distinguished from a tomcat's caterwauling from a rooftop. The one is the love song that the female chooses, the other the sound of the sexual impulse in all its naked desperation. In this respect the philosopher will not allow something of natural beauty to be flattened out into the sex drive; he recognizes that drive as a starting point, but he refuses to rely on it as an explanation of the thing in and of itself. An explanation from

2

3

4 By analyzing the parts-to-whole ensemble of the solov'inaia pesnia Solov'ev, as much a poet as a philosopher, could be punning on his own name. 
origins is not the same as an explanation from ontological fact, from what the thing, in and of itself, is now: 'The question 'What is a known object?' never corresponds to the question 'From what or whence came this object?'"5 There is something in that integrating third element that cannot be fully illuminated by establishing where it came from. Its growth, evolution, in time and space makes of it something more than the urge to be born or to be fed. That's why Solov'ev himself was constantly hovering between Sophia as the material world in its current realization and Sophia as that same world in its future potential. She is both/and.

With this aside we can now circle back to CE's unique role as scholarly interlocutor (in Russian, sobesednik) and thinker. The clamp here is gender: Solov'ev's Sophia is a female principle (there can be exceptions) and CE's way of entering a dialogue partakes of that same principle. I would even go so far as to say that it, that principle as CE has practiced it, is "wise" in the way Solov'ev imagined. How can one make such a claim? First, because CE is an intellectual facilitator (an "in-between" consciousness) of the highest order. Her verbal incarnation is the response: "the only thing that can make us whole is a response,"6 she repeats after Bakhtin in her piece on his early philosophical essays. As a personality in words she relates to others' ideas in such a way as to make those ideas come alive and, in the process, morph into unexpected "thirds." She is not afraid to serve an idea because it is the idea, not the individual carrier, that matters most (Bakhtin's socalled impersonality and his indifference to individual fate). As she wrestles with Bakhtin's original use of polyphony in the Dostoevsky book she both points out the ideational nexus giving birth to the term (the Russian Silver Age) and provides ample space to those critics (Kariakin ${ }^{7}$ ) who argue, often persuasively, that creating hero-ideas who are on equal speaking terms not only with each other but their author seems to ignore important aspects of authorial design, including the shaping of beginnings and ends (Bakhtin was a "middle"-obsessed thinker), the internalized logic behind the fates of individual heroes, the plots (Bakhtin was also not plot-oriented) that appear to lead in certain directions for certain reasons. She takes the "material" of Bakhtin's idea (polyphony), shines the light of other's objections on that material, and as a result comes up with the "diamond" of why polyphony

Solov'ev, Filosofiia iskusstva, 46.

"The Early Philosophical Essays," 46.

See discussion in "Polyphony and the Carnivalesque: Introducing the Terms," 7-8. 
is still necessary to understand a great author's poetics and how it can still work in spite of what we know.

Bakhtin was fascinated with scientistic models. He had come to maturity in an era fascinated by numerical manipulation and classification: series, sets, groups, the emergence of sociology as a profession. Numbers lent themselves to grids and structures. And much like Wittgenstein at a slightly later time, Bakhtin was concerned to preserve the principle of relationalism without endorsing system-based structuralism (and why indeed should relationships, to be valid, organize themselves into a system?). ${ }^{8}$

This is a really brilliant move for the reason that it takes us to an entirely different "third" that is based on Bakhtin and his critics but is a step further and, I would argue, a step into the future, that is, a step that opens things up beyond us. The dialogism and polyphony of Bakhtin's starting point are attempts, in a post-Einsteinian universe, to preserve the integrity of the relational - the "answerability" of the I-thou relationship - in a context where everything could become, and for many has now become, purely relative, as in purely situational, ephemeral, fungible. I would add only that Sophia is somewhere in this focus on the relational as opposed to the relative.

The perfect balance that Solov'ev looked for in worldly Sophianic incarnations comes through in CE's writings as a keen simultaneous awareness of how the ethical and the aesthetic, having shed any idealistic residue, combine not as essences but as productive tensions, parts striving to be, but never actually becoming, wholes. In terms of style and substance, CE is an indefatigable intellectual cross trainer. Translations from one language to another, one thought system to another, one historical context to another, that are elegant, precise, painstakingly nuanced. Beauty that focuses on the future more than the past, that is "assigned" [zadan] and not "given" [dan], ${ }^{9}$ that works on itself and builds off its imperfections and mistakes more than it rhapsodizes about perfect physical bodies or symmetrical form - fruit whose fate, despite its captivating presence/present, is to become ripe, overripe, and then to fall. CE's different discussions of Bakhtinian carnival is a good example of this homeostatic tension. First, she explains why carnival has been such a fertile concept for the academic left over the previous half

Ibid., 27.

“The Early Philosophical Essays," 46. 
century, inspiring inter alia Paris 1968, British postcolonial theory, Latin American literary practice, and continental and American feminist thought. "Carnival space," "holiday time," "rejuvenating laughter," and the "grotesque body" come together to produce a heady brew that "requires no special effort" to affirm. ${ }^{10}$ So here again we see $\mathrm{CE}$, in between Bakhtin and his western acolytes, moving in to set the record straight: with one leg amputated and no stranger to pain and infirmity (his chronic osteomyelitis), Bakhtin was anything but carnivalesque and fixated on the "lower bodily stratum" in his personal behavior; he had to defend his dissertation (the Rabelais book) at home against charges of "ideological depravity" and, yes, as he explained at the defense, he understood that he had dehistoricized the French writer and overstated the medieval worldview (which was already becoming infected by renaissance values) by boiling it down into essentialized binaries (official vs. unofficial culture, common people vs. privileged classes, public square vs. private space, etc.). ${ }^{11}$

But it is not only the what of Bakhtin's revolutionary understanding of carnival, including its exaggerations and oversimplifications, that interests $\mathrm{CE}$, although she is as historically accurate as possible in laying out his positions. Equally if not more important is the why, for here is where the dialogue opens again and creates another third. Bakhtin was aware of what he was doing, but more than writing scholarship (cf. the divide between philology and philosophy, Mikhail Gasparov and Bakhtin, that is the subject of another of CE's essays) he was writing the life of ideas, trying "to catch existence in the process of becoming,"12 and in this instance overstatements were necessary to punch out his points. Laughter has to be "fearless" - an attitude relevant not only to Rabelais's time, but to Bakhtin's as well. To be sure, "Bakhtin functions more as a mythographer than as a literary scholar and social historian. Perhaps mythography suited Bakhtin's intent." 13 As long as we call things by their right names and take a responsible position in between, we can remain true to Bakhtin's post-Kantian answerability imperative. For Bakhtin as well as for CE, "meaning must always grow." 14 There is no fear of overheated talking cures

"Polyphony and the Carnivalesque: Introducing the Terms," 31-32.

See discussion in ibid., 31-38.

Cited ibid., 36.

Ibid., 38.

"Coming to Terms with Carnival," 60. 
or of professors enamored with the sound of their own voices because the interlocutor is listening to the other, "signing" for his actions.

Our cognitive and creative forces are fueled not by reflections but by answerability, that is, by interaction between different, only temporarily consummated selves.... In his [Bakhtin's] understanding, our psyches are constructed to be curious about difference, not hostile to it or frightened by it. What marks "true love experience," then, is nothing necessarily erotic or possessive - and certainly nothing neurotic or compulsive - but rather a cognitive quality, a concentration of attention that enriches the beloved over time with extraordinary individuated responses. ${ }^{15}$

This same attitude and angle of vision apply to those CE calls the "master workers," the classics of Russian literature's Golden Age. Lest the reader forget, the scholarly industries surrounding these figures are truly massive, yet $\mathrm{CE}$, through decades of hard work and an appetite for learning and absorbing others' thoughts that is seemingly inexhaustible, has made herself at home in this welter of primary and secondary sources. Even when engaging the most poetic of writers, Alexander Pushkin, CE finds new and heuristically challenging ways to open closed structures and reground the artist's (and human being's) urge to transcendence. The poet's Tatiana may be a muse figure or a "standing wave"16 of beautifully untapped potential; she may also be something the hero Onegin dreams in order to prod him back to life and change from his overdetermined Byronic role-playing. This latter reading is certainly provocative, and CE knows it. In the spirit of dialogic fair play, much like her inclusion of Bakhtin critics in her pieces on polyphony and carnival, CE goes on in a postscript to cite the horrified Russian response to her assault on the Tatiana cult, which she presented as nothing more than a hypothesis. Maybe there was something in her presentation that seemed flippant, not sufficiently respectful (Russians, and not only Russians, have been falling in love with the Tatiana of chapter eight from the beginning), too comfortable with the democratic play of ideas. On the other hand, to call CE's argument a product of the "idle trivialized consciousness of the West,"17 as the offended Tambov professor does, is a gross misrepresentation, which needs to be rebutted, and which CE calmly rebuts. Elsewhere she

\footnotetext{
15 "The Early Philosophical Essays," 50.

16 "Pushkin's Tatiana," 142.

17 Ibid., 155.
} 
demonstrates with exemplary close readings how Chekhov's different "Annas" (from the stories "A Calamity" [Neschast'e], "Anna Round the Neck" [Anna na shee], and "Lady with a Pet Dog" [Dama s sobachkoi]) take the potential fate of their Tolstoyan namesake into prosaic post-affair territory: what does it mean if we avoid the suicidal grand gesture and continue to live out our messy, mistake-ridden, yet still answerable lives.

Chekhov, so great a master at the malleable and the tender in human relations, opens Tolstoy's novel up to new confusions and compassions. Konstantin Levin might not have been so lucky. Anna's terrible denouement might be avoided. There will be a price, of course, for doing so, for suicide is an elegant one-way gesture and splendid closure; but that too is part of Chekhov's re-novelization [Bakhtin's concept-DMB]. Chekhov and Tolstoy had different ideas about closing things down. ${ }^{18}$

There are moments in CE's studies of the classics that are such crystal clear distillations of her way of thinking and being and are at the same time such gems of vigorous scholarly recuperation transformed into abiding insight that one has to hope they will take their place among the future highlights of the tradition (if there is a tradition). In an earlier article not included in this collection ("'The Queen of Spades' and the Open End"), ${ }^{19}$ CE comes at Pushkin's famous problematic text in a novel (in various senses) way. Structuralist commentators and New Critic types have been attempting for years to find the key to this tale about gambling through numerological code-cracking and ingenious word and root play (paronomasia). Why does Germann choose the wrong card, the queen instead of the intended ace? Guilt, fantastic intrusion of a revenant, verisimilar powder that causes cards to stick together? In effect, suggests $C E$, the critics are searching for the secret that will unlock the magic box of the story just as the hero Germann is searching for the three cards that will win him his fortune at faro. But the true gambler, the one who takes risks and doesn't try at every turn to hedge his bets, works with pieces of codes, hunches about this combination or that combination. The true gambler will take a chance on love (Liza) and not use the other in a cunning game to get at the countess and her supposed secret. Although Pushkin was a poet (and gambler!) to

18 "Chekhov and the Annas," 252.

19 Caryl Emerson, “The Queen of Spades' and the Open End," in Puškin Today, ed. David M. Bethea (Bloomington: Indiana University Press, 1993), 31-37. 
his bones, this reading seems much closer to what he was striving for in his story (and in his life-art relations) and for that reason deserves a robust life now and in the future. It is not the tidy closedness of the elegant structuralist reading, nor is it the complete openness of an anything-goes indeterminacy; it is that relational in-between that we sense is a striving in the right direction.

Another perfect pitch moment of "participative thinking" [uchastnoe myshlenie], ${ }^{20}$ where one senses strongly both CE's voice zone and the felt reality of her interlocutor, involves drawing the notion of evil in Dostoevsky and Tolstoy through the prism of J. M. Coetzee's novel Elizabeth Costello. Here again, the ability to pose the questions in this way, with this stunning cast of characters and their mental worlds understood so deeply and broadly, is uniquely $C E$ 's:

Where Dostoevsky and Tolstoy would agree is that great art should slow us down. It should take up time and make us think. Both would insist that the cooption of art by the marketplace, by the corporate values of speed, power, consumerism, instant gratification and instant depletion leading to more consumption, is an obscenity and a disaster. To adjust art to the historyless pace and corporate values of commercial life in hopes of making it "relevant" is to eviscerate it. Art cannot turn back the clock, of course, but it must provide an alternative to the clocks that happen to be ticking today, together with their limited understanding of life. All art (and especially art of the great novel) is time intensive; it does not come ready-made, it is a striving. For all their different routes to this truth, both Dostoevsky and Tolstoy would agree that human beings are not built to benefit from immediate pleasures, cognitive or physical. What we need is the sense that the universe contains values or truths that must be searched for. ${ }^{21}$

Powerful words, essential words, words that express the cognitive tough love that $C E$ practices as she tries to bring her readers into alignment with a world once inhabited, and hopefully still inhabited, by giants like Dostoevsky and Tolstoy.

CE's final broad area of interest involves the conceptual and aesthetic challenges related to adapting literary texts to other art forms. This interest

20 The term goes back to Bakhtin's early writings. See discussion in "The Early Philosophical Essays," 45.

21 “Tolstoy and Dostoevsky on Evil-Doing," 221. 
began three decades ago with her first book ${ }^{22}$ and the historiography (Karamzin's History of the Russian State)/historical drama (Pushkin's Boris Godunov)/opera (Musorgsky's Boris Godunov) axis. In recent decades it has exploded to encompass theater as well as opera. Among the figures and works engaged by $C E$ in the essays collected here are Tchaikovsky (Pushkin's Eugene Onegin), Dargomyzhshky (Pushkin's Stone Guest), Rimsky-Korsakov (Pushkin's Mozart and Salieri), Cui (Pushkin's A Feast in Time of Plague), Rachmaninoff (Pushkin's The Covetous Knight), Prokofiev/Krzhizhanovsky (Pushkin's Eugene Onegin), Meyerhold/Prokofiev (Pushkin's Boris Godunov), Shostakovich (Leskov's Lady Macbeth of the Mtsensk District). Even when the originary text is historical and not strictly literary, as in Musorgsky's Khovanshchina, there is still the question of authenticity, versimilitude. "How," asks CE, "does one embed a historical event in artistic form so that the product is both true to history and true to art?"23

These essays that bring together CE's comparative expertises as literature, music, and theater scholar are some of the most intellectually daring ever undertaken by an American humanities professor, much less a Slavist or Russianist. CE's ability to mediate among discourses and to eschew the precious without dumbing down or slipping into generality is breath-taking. We see this vividly in "Little Tragedies, Little Operas," where the kuchkisty (the members of the Balakirev Circle or the "Mighty Handful"/ Moguchaia kuchka: Milii Balakirev, Modest Musorgsky, Alexander Borodin, Nikolai Rimsky-Korsakov, Cesar Cui) take up the challenge of composing operas whose libretti are true to the words of Pushkin's Little Tragedies. This radical (as in anti-conservatory) orthodoxy can backfire, however, when fidelity to one form creates a sense of rigidity and ploddingness in the other. Transposition is precisely that: not a literal translation from one form/genre/ mode to another (impossible), but a "positing over," a "placing again" that captures the essence, the spirit, of the one and resituates it in the other.

Their [the kuchkists'-DMB] opponenets in the Turgenev-Tchaikovsky camp, also worshipers of Pushkin, were not persuaded by these efforts. To them, this clarion call to "be true to the source text" was worse than misplaced fidelity; it was mistaken identity, a failure to understand UP, 1986).

“From 'Boris Godunov' to 'Khovanshchina', 284. 
fundamental rules of musical genre and the musician's role in creating a synthetic work of art. If a play or any other complex literary narrative "goes into music" without resistance and without adjustment, it could only suggest that the original was imperfect or inadequate, in need of a supplement. An "accurate" musical hybrid would not be homage to Pushkin, but quite the opposite. ${ }^{24}$

Likewise, in the conceptually adventuresome Khovanshchina piece CE demonstrates how Musorgsky by this stage of his career had evolved away from his understanding of historical time in his two Boris's and moved toward something in this unfinished masterwork much more baffling for the contemporary viewer to appreciate: the Endzeit of the Old Believers. There is still a versimilitude of sorts, but it does not equate to being unconditionally faithful to historical character (the different Old Believer-inspired revolts during the late seventeenth century are here telescoped and intermixed), to historical language (archaisms surface when phrases from documents are cited or certain characters speak, but other than that the language is contemporary to that of the audience), or to historical music (the native folksongs or church-style chants do not actually reflect seventeenth-century harmonies or musical forms). The verisimilitude that matters in the opera is, again, somewhere between history and art (what is true to both but can't be expressed wholly in one mode or the other): the idea that the Old Believers "have given up this world" and that their function "is to stop time." 25 This obviously changes the way we process the roles of characters like Marfa and Dosifei. These latter aren't simply representatives of a murky obscurantism being satirized by the populist and progressive Musorgsky (the standard Soviet take); rather they are witness to a terrifying world, presumably one the composer is now attempting to embody in all seriousness, whose inhabitants "are eternally alert, but... can hear or desire nothing new."26

In this third category (artistic transposition) of CE's many remarkable achievements two stand out as exceptional and as worthy examples, if not of closure (zamknutost', which really does not exist either in Bakhtin's or in CE's worlds), then of momentary completion (zavershenie, or a positive topping-off). ${ }^{27}$ The first is her intense involvement with the premiering of

\footnotetext{
24 “Little Operas to Pushkin's Little Tragedies," 320.

25 “From 'Boris Godunov' to 'Khovanshchina'," 291.

26 Ibid., 297.

27 See "Polyphony and the Carnivalesque: Introducing the Terms," 39.
} 
a "concept": Princeton's April 2007 production of the uncensored original 1825 version of Pushkin's Boris Godunov. The event was termed a "concept" and not a revival or restoration precisely because nothing about this play had ever been completed as originally planned. In this version, for starters, the work had twenty-five scenes, not twenty-two, and Pushkin called it a komediia [comedy], which changes a great deal. By the same token, the 1937 attempt to stage this Boris, at the height of the Stalinist purges, with the brilliant Meyerhold feverishly rehearsing and the recently repatriated Prokofiev providing a score, had remained, for obvious dark historical reasons, unfinished. A perfect event for Bakhtinian loopholes, backward glances and dialogues that refuse to close down! That this massive undertaking involved the close and complex collaboration of faculty, student actors, and various campus units; that news of it attracted major media attention, with performances selling out; and that the production itself, with its set design featuring illuminated "bungee cords" (what the actors did with this refashioned surgical tubing as they were speaking their lines reflected their emotions and moved the plot along), was powerfully innovative - all this speaks to the degree to which $C E$ has taken her interest in living ideas out into our century's version of the public square. To read the testimonials and exuberant post-mortems by the student actors, who were themselves caught up in the quest for authenticity and whether finding ingenious ways to change costume or possessing the stage presence to adapt to the unforseen entered energetically into this fanciful modernist "reconstruction" of what had never before been performed, there emerges the definite sense that high culture can still be stunningly alive, that it need not be brought low to be brought out.

Last but not least is CE's current restoration project involving the "ethnically Polish, Ukrainian-born Russophone prosewriter-playwright Sigizmund Krzhizhanovsky (1887-1950)."28 The multi-faceted, long neglected Krzhizhanovsky seems tailor-made as a career-capping focus for CE. First and most obvious, Krzhizhanovsky was involved, however precariously, in another Pushkin centennial undertaking, this one a stage adaptation of Eugene Onegin, commissioned by Tairov's Moscow Chamber Theater, and replete with a Prokofiev score composed for the occasion. Once again $C E$ and her Princeton colleagues and students will try, this time 
in February 2012, to bring to life what Stalin, his cultural commissars, and — truth be told — the Pushkin purists thought should be permanently put to sleep. The conceptual issues surrounding this transposition will be as challenging, if not more so, than those raised by the 2007 Boris production. In bringing Pushkin's novel-in-verse to stage, for example, Krzhizhanovsky considered making the sorts of changes - removing the work's intrusive narrator, interlarding the action with fairytale and elegiac snippets from elsewhere in Pushkin's oeuvre, and most importantly and vividly, presenting Tatiana's pivotal wintertime dream in her own voice and from her own view - that go to the heart of the transposition process. In other words, the writer-thinker was attempting not to clone Pushkin's work but to create something on stage equivalent to it. And because so many of Krzhizhanovsky's most cherished ideas seem uncannily to hark back (presumably unconsciously) to notions of Bakhtinian dialogue, there appears to be a kind of happy homecoming to this new venturing out.

$\mathrm{CE}$ is finding substantial grist for her ever-active intellectual mill both in the still untranslated contents of Krzhizhanovsky's Collected Works (in five volumes, 2001-06), which she is duly bringing into the Anglophone orbit, as well as in her subject's Moscow archive. These writings include studies "on drama... original comedies, stage and radio-show adaptations, pantomimes, war-time libretti, feuilletons of Moscow in history and under seige, essays on theater (both as philosophy and technical craft), and interpretations of classic English repertory, especially Shakespeare and George Bernard Shaw." ${ }^{29}$ Most telling, in this sprawling body of work, which is not new but can now be experienced as such, CE meets an array of personified ideas and viewpoints whose words, not going away, sound strangely familiar: "His [Krzhizhanovsky's] hero everywhere was the idea [mysl'] trapped in the brain. This idea, or individualized thought, has one task: to survive and grow by searching out the freest possible carrier, the person or plot that would least obstruct or obscure it on its journey." 30 We are back to the primacy of the idea (the intellectual genetic code, as it were) and the ephemerality of the carrier (provided the latter is free and able to take its cargo to new open spaces). There is even, one might say, a carnivalesque quality to this new dialogic partner: polymorphous, always shifting and evolving figuratively if not literally, unwilling or unable to play by the rules, given to construct

"Eugene Onegin on the Stalinist Stage," 378 Ibid., 379. 
original thought groups around famous kindred interlocutors (Rabelais $\rightarrow$ Shakespeare, Swift), driven by a wacky spatial poetics where sounds are constantly being squeezed through narrow apertures to find their way out (cf., again, Rabelais and the "lower bodily stratum"). But whereas Bakhtin reprised a public square-space designed to produce carnivalesque inversions to official culture, Krzhizhanovsky turns his attention to the dream-space of the theater and to the everpresentness of performance. Meaning must always grow. If there is an important difference between Bakhtin and Krzhizhanovsky as thinkers, however, it is that the latter is in his way more "aristocratic," more a proponent of the idea in its own right. By the same token, he feels less obligated to respond.

Let us hope, then, as CE proceeds to immerse herself in the living envelope of ideas that is Sigizmund Krzhizhanovsky, that the words don't go away. May her dialogues with the artistically and metaphysically acute find a new generation of readers as eager to engage with, and learn from, her special brand of luminous answerability as we have been. Great art should slow us down. So should the essays in this volume. 